\title{
Goddelike onberekenbaarheid en menslike toerekenbaarheid in die boek Amos
}

\author{
J.L. Helberg \\ Departement Ou en Nuwe Testament \\ Potchefstroomse Universiteit vir $\mathrm{CHO}$ \\ POTCHEFSTROOM
}

\begin{abstract}
Divine incalculability and human accountability in the book of Amos

The book of Amos is characterised by unexpected and even disillusionary divinc action. Especially the promise at the end of the book is therefore regarded by many commentators as inconsistent with the gemine proclamation by Amos. This part of the book of Amos is thus regarded as the product of later redactionary activity. The author of this article sees the answer to this problem in the absolute sovereignty of God which dominates all parts of the book. Neglect of this aspect of God, combined with his personal will, caused Israel to practise an impersonal religion and made them fully accoumable to this God who is incalculable in his action but not in his claim. Israel boasted about its history of salvation, but was blind to the responsibility it implied toward God and the neighbour. In selfsatisfaction the Israelites thws reversed the covenamt history. God did the same, but in his own way and time. It thus seemed as if the end had come for Israel. Even so, the possibility of hope expressed by the word "perhaps" and the phrase "my people" indicating God's bond with Israel (5:15 \& 7:15). imply the absolute sovereignty of God to pumish as well as to redeem.
\end{abstract}

\section{Inleiding}

Die verkondiging van die boek Amos word gekenmerk deur onverwagte en selfs ontnugterende Goddelike optrede. Israel verwag die Here se guns maar loop hulle dwarsdeur die boek telkens teen sy toorn en straf vas en stuur onkeerbaar op ondergang af. Dan, teen die einde van die boek, wamneer alles vir Israel verlore is en die breuk tussen die volk en die Here finaal is, kom die onberekenbare Goddelike optrede op 'n omgekeerde manier voor. Onverwags en ongemotiveerd word redding aangekondig, sonder enige sprake van 'n verandering of optrede van Israel se kant $(9: 11-15)$.

Volgens baie teoloë is die boek die vrug van verskillende redaksies. Hierdie artikel kyk kortliks na die kwessie van die eenheid van die boek en kom tot die gevolgtrekking dat die probleem teologies egter nie opgelos word deur verskillende redaksies te aanvaar nie, maar slegs verskuif word na verskillende benaderings deur Amos en redaktors. Hier word nou na die teologiese probleem gekyk en die vraag vir ons doel is dus nie of daar verskillende redaksies was nie, 
maar eerder of Amos se verkondiging teologies 'n eenheid is. Kan sy verkondiging ál die verskillende fasette wat in die boek voorkom, teologies akkommodeer, ook dié wat die vrug van redaksie sou kon wees? Die antwoord is dat dit in al hierdie gedeeltes in die boek veral gaan om Goddelike vrymag. God se onberekenbaarheid in verband met straf sowel as herstel moet in hierdie lig benader word.

Daarmee word wel die vraag opgeroep hoe die onberekenbaarheid gerym kan word met toerekenbaarheid of aanspreekhkheid vir Israel as hulle iets teen die wil van die Here doen. God se optrede en dus sy wil is immers selfs telkens die teenoorgestelde van wat hulle verwag. Uit die bespreking sal blyk dat volgens die boek Amos die Here onberekenbaar is in sy optrede, maar nie in sy eis waaraan Israel gemeet word nie, want hierdie eis is duidelik.

'n Regte siening op Amos se verkondiging kan ook lig gee in Suid-Afrika waar die hele kwessie van berekenbaarheid en die toerekenbaarheid van menslike optrede en van gebeurtenisse vandag na vore kom rondom die Waarheids- en Versoeningskommissie. Ook die optrede van God word geraak omdat Hy uiteindelik tog alles bepaal $(1: 2 ; 1: 3-2: 16 ; 3: 6 ; 5: 8,9 ; 7: 5-6,7)$.

\section{Die eenheid al dan nie van die boek Amos}

\section{- Redaksies}

Markert (1977:1, 220-223, 295, 296) bevind dat daar in Amos nie 'n eenvoudige onderskeid is tussen Drohwort, wat waarsku en dus bekering op die oog het, en Scheltwort, wat veroordeel nie. Hierdie feit mak dit nodig om op ander maniere na die verhouding tussen die woorde van Amos self en moontlike redaktors te kyk. Reeds Wellhausen het gesê dat 9:11-15 van "rose en laventel" praat teenoor Amos se "bloed en yster". Amos 1-3 en die visioene ( $7: 1-8 ; 8: 1-2 ; 9: 1-4)$ word oor die algemeen aan Amos toegeskryf. Wolff (1969:130-138) onderskei verder gedeeltes van Amos se leerlinge; 'n Bet-El-redaksie in Josia se tyd, 'n deuteronomistiese redaksie en 'n na-ballingskapse heilseskatologie. (Vgl. ook Rottzoll, 1996:1-5, 285-290 oor die boek Amos as 'n redaksionele eenheid.)

Prinsloo (1987:245) meen tereg dat die blote feit dat oordeelsaankondiging in heilsprofesie oorgaan, nie voldoende rede is om 'n ander outeur te aanvaar nie. In 9:11 en 15 word die ballingskap egter as voldonge feit aanvaar en daarom neem hy 'n na-ballingskapse datering daarvoor aan. Blykbaar speel sy volgende stelling (1987:240) in verband met Amos 9:7 ook 'n rol in sy beoordeling: "Israel beklee dus nie 'n bevoorregte posisie onder die volke nie. Inteendeel, die toorn van God kom veral op hulle neer." Amos 9:7 moet egter nie simplisties gesien word nie. Amos ontken in werklikheid nie die besondere verhouding tussen die Here en ander nasies nie, maar hy maak wel ander gevolgtrekkings daaruit, naamlik oor verantwoordelikheid. 
Childs $(1979: 400,401,407)$ beklemtoon die teologiese eenheid van die boek, soos blyk uit die opskrif (1:2), maar sien tog in die slot 'n verskil in omstandighede met die res. Die boek reflekteer volgens hom 'n teologiese konteks wat die oorspronklike boodskap van Amos in verskeie opsigte transfonneer om die profetiese woord as 'n kritiese norm vir toekomstige geslagte in Israel te laat funksioneer. Soggin (1987:22) wys op die negatiewe en pessimistiese konteks waarin die enkele uitsprake oor redding voorkom en sien dit as vrug van 'n tyd toe die oordeel reeds plaasgevind het. Slegs die besef dat die oordeel gekom het, dat die skuld betaal is (Jes. 40:1 e.v.), kon vertroue in die jare wat voorlê, herstel - 'n sekerheid dat God nie die dood van sy volk wil nie, maar bekering en lewe. Hierteenoor geld egter dat, anders as in so baie ballingskapse en na-ballingskapse tekste, daar in die betrokke gedeeltes in Amos geen verwysing is na sonde en versoening, terugkeer van die verstrooides of ' $n$ Messias nie; verder dat politieke aspekte daarin 'n geringe rol speel.

Volgens Firth $(1996: 381,382)$ lê die oplossing daarin dat 9:11-15 op twee "vlakke" funksioneer: 'n mondelinge vlak wat as oordeel gerig is teen Israel, en 'n literêre vlak wat as hoop gerig is tot Juda. Fritz (1987:38) oordeel dat die verkondiging teen die nasies nie die vrug van profetiese openbaring is nie, maar 'n geskiedbeskouing wat gegroei het uit die bedreiging deur die opkomende Assirië, naamlik dat Jahwe teenoor Israel opgetree het soos Hy teen die ander volke opgetree het. Volgens Koenen (1994:271-274) is die verkondiging van die profete self radikaal en plaas hulle die fokus op die tydelike situasie. Ballingskapse en na-ballingskapse teoloë het egter redaksionele wysings aangebring, onder andere in Amos 9:8b-10, deur die profetiese verkondigings met 'n algemene en tydlose betekenis te beklee. Daarvoor word profetiese heilsaankondigings op die regverdiges betrek en die onheilsaankondigings op die sondaars. Hierteenoor geld egter dat hierdie onderskeid nie in die slot van Amos (9:11-15) geld nie.

Uit die voorgaande blyk dat die aard van sommige gedeeltes deur baie verklaarders as teenstrydig met die aard van Amos se verkondiging gesien word.

\section{- Eenheid}

Hasel $(1981: 22-25,119,120)$ wys op benaderings wat tot die konklusie kom dat die boek nie die vrug van 'n lang redaksieproses was nie. Hy pleit vir die erkenning van 'n pluraliteit van metodes naas die vorm-kritiese en redaksiekritiese wat in gebreke bly om eenheid raak te sien. Die finale, eskatologiese einde van die Noordryk se nasionale bestaan word verkondig, maar behels nie die absolute einde van alles daaromtrent nie. Daar is steeds 'n "dalk" - die moontlikheid van God se genade en dus 'n egte moontlikheid van 'n "oorblyfsel" uit die huis van Josef (5:14-15). Van Leeuwen (1985:343-346) weeg die verskillende gegewens teen mekaar op en oordeel dat daar geen prinsipiële rede 
is om sommige gedeeltes nie aan Amos toe te dig nie. Dieselfde geld van Smith $(1989: 278,279)$. Hy stel verder (1989:13) dat die teologie van die boek swaar gekonsentreer is op die optrede van God; met ander woorde dat dit sterk teosentries is. Barstad (1984:6-10) kritiseer teoloè se oorheersende belangstelling in etiese aspekte ten koste van die religieuse; die profete se hoofdoel was om aan te dui dat God die enigste God is wat waardig is om aanbid te word.

Vervolgens sal verder ingegaan word op die inhoud van die verkondiging in die boek Amos en gekyk word of Amos se verkondiging die gedeeltes wat moontlik redaksionele toevoegings is, han akkommodeer.

\section{Toerekenbaarheid en berekenbaarheid in verband met Israel}

Die sondes van Israel was nie maar net sondes van individue of sporadiese sondes nie, maar was algemeen en volgens 'n vaste patroon. Daar was 'n bepaalde benadering of teologie wat die goedkeuring van die openbare mening, die staat en die godsdienstige instellings weggedra het. Die basis waarop hiervoor gebou is, was nogal die geskiedenis van Israel as volk van Goddelike verkiesing, soos hieronder sal blyk. Daar was dus iets wesenliks verkeerds.

Reeds in die opskrif (1:2) word sowel die onberekenbaarheid van die Here as die toerekenbaarheid van die hoorders benadruk: "Wanneer die Here uit Sion brul, verdor die weivelde van die herders en verdroog die top van Karmelberg". Die Goddelike vrymag kom ook sterk na vore in die manier waarop Amos tot profeet geroep is $(3: 8 ; 7: 14,15)$. Amos was eintlik 'n veeboer en kweker van wildevye en was dus nie vir hierdie taak opgelei nie. Hierdie feit beklemtoon ook die onberekenbaarheid van God ten opsigte van die inhoud van die boodskap wat Amos moet bring.

\subsection{Israel is volgens Amos ingelig oor hoe hulle moet optree}

Volgens Amos kan die Israeliete hulle optrede en die gevolge bereken en is hulle daarom toerekenbaar. Reeds wanneer die Here Israel begin aanspreek, gee Hy 'n opsomming van hulle geskiedenis in verbondenheid met Hom: hulle het gefaal deur sy instellings te minag en sy profete stil te mak (2:9-12). Wanneer Amos vir Israel hier op verrassende en ontnugterende manier hulle straf aankondig, motiveer hy dit deur hulle sondes te noem: swak moraliteit, veral in verband met reg en geregtigheid $(2: 6,7)$, en vormgodsdiens in die kultus. Die kultusbeoefening stel nie hierdie sondes aan die kaak nie, maar is eerder ' $n$ verlengstuk daarvan en 'n vervalsing van die godsdiens (2:8). Die Israeliete maak van die Here 'n God volgens eie sinaak en daarom praat Amos van "hulle God". Dit is nie werklik die Here vir wie hulle in hulle godsdiensbeoefening dien nie. Hulle voer nie sy wil, soos in sy wet gegee, uit nie. In die Bondsboek (Eks. 21-23) word tog gesê dat klere wat verpand is, voor sononder aan die eienaar teruggegee 
moet word, want "onder wat anders kan hy slaap? (Eks. 22:26, 27; Fensham, 1970:144-146). Israel hou nie daarmee rekening nie dat die Here die beskermer van die swakkes is en dié wat hulle veronreg, straf.

Tog verwys Amos nie na die wet as sodanig nie. (Hy beoordeel ook die nasies nie op grond van intemasionale bepalings nie - Barton, 1980:2, 59.) Ook word die wet as entiteit op sigself nie in hierdie verband beklemtoon nie. Trouens, Amos probeer nêrens sy verkondiging met 'n beroep op die wette regverdig nie (Van Leeuwen, 1985:19). Hy kla Israel wel daaroor aan dat hulle hul godsdiens laat opgaan in 'n formele belydenis van die heilstradisies en in vormdiens. Daarom word hulle voor die praktiese en persoonlike aard van die godsdiens gestel, net soos Amos by sy roeping. Reg en geregtigheid hang in Israel juis ten nouste saam met die regte verhouding teenoor die gemeenskap (Koch, 1976:514; Johnson, 1989:922; Liedke, 1976:1004, 1005; Preuss, 1992:179). Hierdie sterk persoonlike aard beheers die hele verkondiging van Amos en loop hand aan hand met die nadruk op God se vrymag.

Ná die negatiewe verwysing na die kultus verwys die Here na die besondere geskiedenis van Israel: die uittog uit Egipte, die vestiging in die land waar Hy die Amoriete uitgeroei het om vir Israel plek te maak en die woestyntog $(2: 9,10)$. Dat die verbond nêrens in die boek Amos by name genoem word nie, hou blykbaar verband met Israel se selftevredenheid en 'n valse gerustheid wat met hulle valse verbondsbenadering geassosieer is. (Op die vraag of die verbond eers van ballingskapse oorsprong is, hoef hier nie ingegegaan te word nie - vergelyk daarvoor Helberg, 1990:81, 82; Oden, 1987:440.) Mays (1974:7) sê tereg dat een of ander vorm van verbondstradisie onderliggend moet wees aan die verhouding geïmpliseer in die benaming "my volk Israel" (vgl. 7:15; 8:2; 9:10, $14,15)$. Wat egter duidelik is, is in elk geval dat die Here van 'n besondere verhouding tussen Hom en Israel praat (3:2), 'n verhouding van verkiesing, maar dat Hy ook iets heeltemal anders hiervan aflei as Israel. Ook hier word nie die gewone term gebruik nie, maar die woord "ken". Amos vermy trouens teologiese begrippe (Wolff, 1969:121), omdat Israel die Here in sulke begrippe ingeperk het en daarmee sy vrymag aangetas het. Die nadruk lê by Amos op die Here se vrye, daadwerklike optrede, soos dit ook gestalte gekry het in Amos se roeping tot profeet en in sy eis om daadwerklike optrede.

\subsection{Die Here verbind die ou tradisie(s) en die profetiese verkondiging}

Die Here wys daarop dat Hy Israel se seuns as profete en nasireërs laat optree het, Inaar dat Israel die nasireèrs laat wyn drink het en dus die Here se godsdienstige bepalings geminag het. Hulle het nog verder gegaan en die profete belet om as profete op te tree $(2: 11,12)$. Israel hou vas aan die godsdienstige tradisie maar vermy en verhoed die praktiese uitlewing daarvan - 'n aspek waarop die verkondiging van die profete juis veral ingestel is. $\mathrm{Na}$ die straf- 
aankondiging hieroor volg die Here se woorde oor die verkiesing van Israel en die verrassende feit dat Hy hulle daarom gaan straf (3:2). Dan word gestel dat daar nie iets gebeur sonder 'n oorsaak nie (3:3-6) en dat die Here nie iets doen sonder dat Hy sy besluit aan sy dienaars, die profete, bekend gemaak het nie (3:7). Hier word dus die profetetradisie asook dié van die verkiesing van Israel $(3: 1,2)$ saam met die ander genoemdes as 'n wesenlike deel van Israel se geskiedenis gesien. Die profete tree op in aansluiting by hierdie tradisie(s); ware godsdiensbeoefening vra voortdurende kennisname van die wil van die Here vir die praktiese lewensituasie. Die profete is onweerstaanbaar daartoe geroep (3:8).

Israel is egter baie duidelik skuldig. Hulle kan vanuit die gevolge terugreken en die oorsaak vasstel. Die ontnugterende straf wat hulle op die lyf gaan loop, kom in werklikheid nie sommer uit die bloute op hulle af nie (3:3-6). Die oorsaak word hier wel net tot die Here teruggevoer, maar Israel (en die nasies) word tog nie werklik onwetend oorval deur die gebeurtenisse nie - inteendeel (3:7).

Israel het van die profete toekomsvoorspellers gemaak wat berekenbaar optree in ooreenstemming met Israel se selfgesentreerde siening van sake en die toekoms; dus in die gees van voorspoed en vrede. Amos daarenteen, sien die hede nie in terme van 'n glorieryke eskatologiese einde nie, maar benader sake vanuit die onregverdige en immorele hede en skilder daarvolgens die toekoms. Hy sê wel wat gaan gebeur en dat dit onkeerbaar kom, maar sien dit tog nie as 'n meganiese, fatalisties berekenbare verloop van dinge nie: Die moontlikheid van genade word geimpliseer in die woord "dalk" - dalk is daar ontferming (5:15).

Ondanks die heilsgeskiedenis van Israel en hulle kennis van wat reg is, kan hulle nie die gebeurtenisse bereken nie, want daar skort iets met hulle rekenvermoë. Hulle "weet nie hoe om reg te doen nie" (3:10). Hierdie leemte geld van al die nasies. Almal stapel oortreding op oortreding (vgl. die refrein oor "drie ... vier" in hoofstuk 1,2). Hier is dus iets meer en diepers op die spel: ondanks Israel se kennis moet hy tog nog voortdurend deur profete, op die basis van Israel se besondere geskiedenis, geleer word wat om te doen en wat om nie te doen nie.

\subsection{Israel moet afgeleer word wat hy wel doen en dink, en die wyse waarop hy bereken}

Daar is ' $n$ totale en radikale verandering by Israel nodig in verband met ware diens van die Here. Die hele boek Amos het te doen met wat Israel tot in die wortel moet afleer: in verband met Israel se benadering van verkiesing (3:2), voorbidding of versoening (7:1-9), die verwagting oor die dag van die Here $(5: 18)$ en die uittog- en intoggebeurtenisse (9:7). Hulle moet afleer om hierdie dinge op hulleself te betrek sonder om 'n verband te lê met die eis van die Here in sy gebooie. In die gebooie word vereis dat die belange van God en die naaste op die 
hart gedra moet word. So word 'n selfgesentreerde benadering by die wortel afgesny.

Die gaping in Israel se uittog- en intogteologie, die gebooie (vgl. Stek, 1978:148, 149), veroorsaak dat Israel se hele benadering van die verbondsverhouding skeef is. Amos konsentreer desondanks nie op die wette nie omdat die formele nakoming ook maar dieselfde resultaat sou hê as meganiese en onpersoonlike kultus, aanbidding en regspleging. 'n Persoonlike verhouding met die Here ontbreek immers. Daarom het Israel nie 'n oop oog vir God se vrymag nie en gaan hulle op in 'n formele, kultiese godsdiens.

\subsection{Volgens Israel se benadering verloop sake volgens 'n vaste, menslik berekenbare patroon}

Volgens bogenoemde benadering is die verloop van gebeure selfs manipuleerbaar deur die nakoming van die kultus en seremoniële pligpleginge. Daarom is Israel vasgevang in selftevredenheid, valse gerustheid, hooghartigheid en selfsug en is hulle onlogies in hulle optrede. Hulle is soos iemand wat perde op 'n klipplaat wil laat galop, of die see met osse wil ploeg! Hulle optrede mis die doel van die bestaan van dinge, van mense en van regspraak $(6: 12)$. Hulle mis ook die doel van hulle eie bestaan as "volk van die Here" (ook hierdie term word weens Israel se selftevredenlheid vermy; Motyer, 1970:726). Hulle sien enersyds hulle verkiesing prakties as 'n saak van lulle eie verdienste in plaas van as vrug van die Here se genade. Andersyds is hulle blind vir die verantwoordelikheid wat die verkiesing meebring en wat in die praktyk gestalte moet kry. Dieselfde geld van die uittog- en intoggeskiedenis, van versoening en voorbidding en van die dag van die Here. Daarom gaan Israel platgeslaan word $(6: 11,14)$.

Volgens die oordeel van Amasia en die volk as geheel is dit die profeet Amos self wat berekenbaar is in sy optrede en uitsprake, vasgevang in 'n konsekwente oordeelsteologie. Hy is veral in hulle oortredinge geïnteresseerd en laat die Here netjies by sy eie oordeelskema inpas. Amos se deemiswekkende voorbidding vir Israel (wat van Amos self afkomstig is; Wolff, 1969:336; O'Kennedy, 1997:99) bewys egter dat Amos tog nie die gevangene van 'n eie, strak oordeelsteologie is nie. Hy het trouens nie self gekies om te doen wat hy doen nie, maar is onder onweerstaanbare Goddelike verpligting geplaas $(3: 7,8)$.

\section{Onberekenbaarheid van die Here se optrede teenoor menslike vertroue op eie berekening}

Wat hierdie aspek betref, gaan dit om onberekenbaarheid, berekenbaarheid en toerekenbaarheid ten opsigte van die volgende aspekte: 


\subsection{Tyd en omstandighede}

Israel is so seker van hulle voorspoed dat hulle hulle nie 'n ander situasie kan indink nie en meen dat dit altyd so sal voortduur. (Vir Israel se omstandighede in hierdie tyd, vergelyk Miller \& Hayes, 1986:307-310.) Trouens, Israel is blind daarvoor dat baie mense tog skreiznde armoede beleef $(2: 8 ; 6: 1,6 ; 5: 21-24 ; 8: 4$ 6). Hiervoor voel hulle nie verantwoordelik nie, maar sien net hulle eie behoefte raak. God sien egter veral die behoefte van die armes en verontregtes raak.

Israel se valse gerustheid en selftevredenheid blyk uit die altare van Bet-El waar hulle hulle selfgesentreerde godsdiens in die gees van weelde, voorspoed, lighartigheid en selfsug beoefen en waardeur hulle die swakkes verdruk en die armes mishandel (3:12-4:5). Die geskiedenis wat inderdaad heilsgeskiedenis moes wees, het daarom 'n geskiedenis geword van straf met die doel om bekering te bewerk. Op al hierdie pogings van die Here het die bekering egter uitgebly, soos gehoor word in die refrein in 4:6-11. Daarom word hulle gedaag om voor die Here self te verskyn (4:12). Hy is die "almagtige God", Skepper en Regeerder oor alle dinge; Hy laat alles gebeur (4:13). Israel besef nie dat die tyd in werklikheid vir hulle swanger aan teenspoed is nie $(2: 6,13-16 ; 3: 10,11 ; 5: 1-3$; ens.). Hulle wou die Here deur middel van die geskiedenis van verlossing vir hulle eiebelang monopoliseer, maar in werklikheid word hierdie geskiedenis omgekeer. Gedurende die uittog het die Here by Israel verbygegaan en die Egiptenaars met straf getref. Daarvan getuig die Pasga wat nog steeds gevier word. Nou sal die Here nie meer by hulle verbygaan nie; nou is dit hulle aan wie die oordeel voltrek sal word (5:17; 7:8; vgl. Eks. 12:12).

Die Here staan heeltemal anders en, vir Israel onbegryplik, teenoor hulle huidige omstandighede. Hulle is bly en vier fees, Hy verafsku hulle feeste. Hulle bring offers, maar Hy vind selfs nie hulle vetgevoerde kalwers aanneemlik nie. Hulle sing en maak musiek, maar vir Hom is dit rumoer (5:21-23). Hulle het 'n verkeerde begrip van die doel en funksie van die kultus en godsdienstige feeste. God het niks van hierdie dinge nodig nie. Dit is nie Hy wat versorg moet word nie, maar hulle, soos Hy gedurende die woestynreis gewys het $(5: 25)$. Hy wil nie strome bloed van offerdiere hê nie, maar strome van reg en geregtigheid in die daaglikse lewe, in die verhouding met die naaste $(5: 24)$.

Israel loop in hulle benadering van die kultus agter ander nasies en hulle gode aan. Daardie gode is egter nie werklik gode nie. Hulle sorg nie; daar moet vir hulle gesorg word. Heel berekenbaar ondergaan hulle dieselfde lot as hulle aanbidders. Die Here daarenteen, is die ware God, nie 'n gemaakte een nie, die Skepper, die Almagtige $(3: 13 ; 4: 13 ; 5: 14,15,27 ; 6: 8,14)$. Hy deel nie die lot van sy aanbidders nie en is vrymagtig in sy optrede. Hy gaan hulle as straf vir hulle sondes in ballingskap laat wegvoer en hulle selfgemaakte gode laat dra $(5: 26)$. 


\subsection{Regspraak en Israel se ander dade}

Die Here is vir Israel onberekenbaar in die regspraak wat Hy gaan toepas. Hulle meen dat hulle onskuldig is en dat hulle die Here se uitverkore volk is, maar hulle kom in werklikheid nie hulle verantwoordelikheid na nie en misbruik hulle bevoorregte posisie (5:7). Dit is juis oor ware reg en regspraak dat die heilsgeskiedenis, wat saamgetrek is in die gebooie, in wese gaan. Daarom tree die Here op as die God wat die Sewester en Orion gemaak het en die donker in oggendlig verander (5:8). Hierdie stelling kan op twee verskillende maniere verstaán word: óf dat Hy dinge volgens 'n vaste patroon bestier, en dus nie wispelturig is nie, of dat $\mathrm{Hy}$ teen die gewone verloop en verwagting van dinge in optree, deur die magtige met vernietiging te tref en vernietiging oor die vestingstad te bring (5:9). Albei betekenisse pas by die tipiese kenmerk van die Here in die boek Amos: die Here is betroubaar, maar nie berekenbaar of manipuleerbaar nie. Hy is vrymagtig

Israel meen dat hulle 'n oorvloed van goeie dade doen. Hulle bring baie soorte offers, selfs van die beste vee, hou feeste en sing en maak musiek om die Here te dien $(4: 4,5 ; 5: 22,23)$. In werklikheid maak hulle 'n berekeningsfout en vermenigvuldig hul sondige dade tot so 'n mate dat die Here lankal nie meer by hulle is nie (5:14) en dat Hy hulle sondes beslis nie meer sal oorsien nie (1:6). In plaas van beloning, soos hulle verwag het, ontvang Israel straf?

Ondanks sy onverwagte en onberekenbare optrede is die Here nie willekeurig nie, maar 'n onveranderlike God op wie 'n mens vas kan vertrou. Daarom lê Hy 'n eed af by Homself (8:7). Die straf vir Israel het 'n baie duidelike motivering; Israel is ryp vir die oordeel $(8: 1,2)$. Hulle inhaligheid en gepaardgaande veronregting van die armes en ander magteloses skrei teen die kosmos $(8: 8)$.

\subsection{Moraliteit in die algemeen}

Al die nasies word voor die oorbluffende werklikheid geplaas dat hulle deur die Here gestraf gaan word oor dinge wat hulle nie as verkeerd beskou het nie. Voorbeelde hiervan is om mense van ander volke te martel of in ballingskap weg te voer, om nie aan ooreenkomste te dink nie, om mense met die swaard te agtervolg, ensovoorts $(1: 3,6,9,11)$. Die volke beoefen dus 'n selektiewe moraal en doen aan ander wat hulle nie aan hulleself gedoen sou wou hê nie. Die Here is vir hulle onberekenbaar in sy straf. Hulle is ook onbewus daarvan dat Hy hulle lotgevalle bepaal en selfs met hulle optree soos met sy volk Israel by die uittog uit Egipte en die inlei in 'n ander land (Am. 9:7). Dit word hier vir Israel gesê as kritiek op hulle selfaanmatigende benadering van die uittoggeskiedenis, maar hierdie blindheid vir wat gebeur, geld ook op 'n soortgelyke manier vir die ander nasies. Hulle behoort die Here ook te ken uit sy bemoeienis met hulle, maar is blind daarvoor. Ook is hulle selfsugtig en aanmatigend in hulle optrede teenoor 
ander. Almal is berekenbaar in hulle gevoel van onskuld teenoor hulle medemense en in die aanwys van skuld by die ander.

Israel neem die Here se optrede teenoor ander nasies anders waar as wat die Here se bedoeling daarmee is. Die verkondiging teen die verskillende nasies is so bepaal dat dit begin by die nasies wat die verste van Israel af staan. Daarna beweeg die oordeel al nader aan Israel self. Israel is blind daarvoor dat hulle as 't ware deur die Here omsingel word (Am. 1-2). Hulle is so voorspelbaar en berekenbaar dat ' $n$ mens presies kan voorspel hoe selftevrede en onbekeerlik hulle gaan reageer op die straf wat Amos aankondig. Hulle sal naamlik dink dat die straf net vir die ander volke geld, nie vir hulleself nie. Dit is trouens in hierdie lig dat die straf wat onmiddellik ná die deerniswekkende voorbidding en beantwoording in 7:1-6 volg, beoordeel moet word. Israel se voorspelbare sondige en onbekeerlike gesindheid en optrede het nog nie verander nie. Hulle bly steeds selftevrede totdat hulle wreed ontnugter word. Selfs as die broervolk Juda die straf van die Here aangesê word $(2: 4,5)$, dring dit nog nie tot Israel deur dat die straf onherroeplik ook op hulleself afpeil nie. Hulle gebruik nie die geleentheid om tot selfondersoek en bekering te kom nie. Dit is trouens 'n berekenbare patroon by hulle (4:6-11). Dan word hulle self wreed ontnugter ten opsigte van hulle verwagtings en berekenings $(2: 6-16 ; 4: 1,2 ; 5: 1,2 ; 5: 17-20$ ens.).

Israel sou hulleself in hulle selftevredenheid kon troos met die gedagte dat die straf by Juda eindig. Juda is immers die sewende in die ry van volke wat die oordeel aanhoor. Sewe is 'n volheidsgetal. Die straf is dus met Juda ten volle uitgemeet! Die Here is egter nie deur menslike berekening ingeperk nie. In 'n sekere sin betaal Hy Israel in dieselfde munt terug vir hulle optrede. Soos hulle by drie sondes 'n vierde voeg, voeg $\mathrm{Hy}$ by sewe strawwe 'n agste! Anders as Israel se optrede is syne egter onverwags. Israel tree voorspelbaar op in ooreenstemming met hulle gewone sondige aard. God tree onberekenbaar op teen sy eie uitverkore volk, soos teenoor Israel se broervolk Juda. So 'n vernietigende oordeel teenoor die eie volk is buitengewoon en ongekend by ander nasies se gode. Elkeen van daardie gode is trouens ook van sy onderskeie volk afhanklik en kan eintlik nie bestaan as die volk self nie bly bestaan nie. Die Here kan egter sonder sy uitverkore volk bestaan. ${ }^{1}$

1 Indien die oordecl oor Tirus, Edom en Juda later bygevoeg is (vgl. Martin-Achard, 1984:7), sou daar aanvanklik 'n sinspeling op die vier oortredings kon wees en daarop dat die Here Israel in dieselfde munt terugbetaal. Rudolph (1971:102) steun egter nie die laat datering nie. Dit waarop Israel nie gereken het nie, wentel in elk geval steeds om die onverwagte straf vir hul optrede en die stelling oor die getal sewe geld in elk geval vir die finale redaksie van die boek 


\subsection{Nasionale en geografiese grense en verkiesing}

Die Here trek grense op ' $n$ ander manier as Israel en die nasies, byvoorbeeld tussen Israel aan die een kant en die Filistyne en die Arameërs aan die ander kant. Israel is vir Hom "nie anders" as die ander nasies nie. Die uittoggeskiedenis neem niks weg van die Here se vrymag in sy optrede teenoor die nasies nie (9:7). In hierdie teksvers word nie slegs 'n negatiewe uitspraak ten opsigte van Israel gemaak en niks oor die ander nasies as sodanig gesê nie. Die stelling spel die Here se vrymag uit. In dieselfde gees moet die uitroep van die Naam van die Here oor die nasies ook in positiewe sin verstaan word (vgl. ook Smith, 1989:12). Die roeping van Amos as profeet uit Juda is een van die bewyse dat God nie nasionaal of geografies ingeperk is nie, maar ook met die nasies besig is.

Die Here nivelleer die verskil tussen Israel en die nasies, nie dié tussen die ware godsdiens en die nasies se godsdiens nie. Hierdie verskil is wel genivelleer deurdat Israel nie leef soos dit 'n uitverkore volk betaam nie. Al die volke of nasies, sonder onderskeid, is skuldig voor die Here. Daar is nie plek vir enigiemand om selftevrede te wees nie; daarom selfs ook nie vir die annes en verdruktes vir wie Amos so pertinent in die bresse tree nie. Die stelling van Albertz $(1992: 259,276)$ dat die profete kant kies vir die annes en dat die Here aan hulle kant is, is daarom te simplisties en eensydig en ignoreer die beklemtoning van Goddelike vrymag.

Die Here regeer oor die skepping en oor die historiese gebeurtenisse, insluitende die lewenspraktyk $(9: 7,8)$. Hy straf die sondige koninkryk vernietigend, want $\mathrm{Hy}$ is 'n regverdige God $(9: 8)$. Tog is dit alleen die sondaars vir wie Hy so straf $(9: 9$, 10). 'n Oorblyfsel van sy volk word gespaar. Hierdie oorblyfsel is hulle wat nie selftevrede is nie. Wanneer die heerskappy van die Here erken word, is daar dus tog uitkoms moontlik. Die Here se trou aan Dawid maak dat sy optrede onberekenbaar is vir mense. Hy bewerk onverwags herstel vir Israel $(9: 11,12)$. Ondanks die radikale oordeelsaankondiging van Amos moet daar dus tog ook daarnee erns gemaak word dat hy sê dat die Here Hom "dalk" sal ontferm oor wat van Josef oor is $(5: 15)$. Verder moet daar erns gemaak word met die honderd of tien oorblywendes wat in die treurlied genoem word (5:3), asook die moontlikheid van 'n oorblyfsel wat oordele oorleef $(3: 9 ; 5: 13,14)$. Dit is met die radikale oordeelsaankondiging oor Israel net so gesteld soos met die kultus van Israel. Die kultus word skerp afgewys, maar - anders as wat vroeër deur baie geleerdes gemeen is - behels hierdie afwysing tog nie ' $n$ teologiese veroordeling van die kultus as sodanig nie, maar 'n praktiese veroordeling (vgl. Soggin, 1982:98; Martin-Achard, 1984:45). 


\subsection{Die heiligdom, vervalste godsdiens en profeetskap}

Die heiligdom in die Tienstammeryk van Israel was 'n staatsheiligdom. Daarin het staatsbelange uit die aard van die saak 'n beheersende rol gespeel. Israel het deur die kultus die Here berekenbaar probeer maak (8:10-13). Die Here daarenteen, laat die oordeel juis by die altaar begin (9:1-6)! Die oordeel is onberekenbaar, onverwags en onontvlugbaar: in die doderyk, in die hemel, op Karmel, in die dieptes van die see, in die vreemde in ballingskap! Verkiesing beteken nie dat die Here ' $n$ klein en beperkte God is nie, maar moet binne 'n kosmiese raamwerk gesien word, want God is Skepper en universele Regeerder.

Israel was vasgedraai in hulle godsdiens waarin die wil van die Here volgens berekenbare menslike benadering vasgestel word, selfs deur die (staats)profete. Dit is 'n geval van "wiens brood men eet diens woord men spreekt". Amasia sê dan ook dat Amos maar in Juda moet gaan optree. Daar sal hierdie verkondiging teen Israel 'n goeie gehoor kry. Daarteenoor stel Amos dat hy nie so 'n soort opgeleide profeet is nie en dus nie praat vanuit menslike, berekenbare oorwegings nie. Hy is deur die Here self geroep en bring dus Goddelike openbaring.

\subsection{Straf, insluitende eskatologiese straf en voorbidding}

Amos sluit aan by Israel se berekenbare hantering van die godsdiens en sê dat ook die straf berekenbaar is; maar op ' $n$ ironiese manier. Die omgekeerde van wat hulle verwag, gaan met Amasia en sy familie en volk gebeur (7:17), net soos die vernames wat hulle "vername" plek behou: hulle word "op die voorpunt van die ballinge" weggevoer (6:7)! Dus, die gevolge van Israel se optrede is berekenbaar, maar op grond van ' $n$ ander uitgangspunt of $x$-faktor as wat Israel in berekening bring. Ware geloofsvisie op verkiesing, naamlik diensbaarheid, word veronderstel, anders is daar ontnugtering met die resultaat van die verwagting.

Israel verwag die dag van die Here as 'n dag van lig en verlossing vir hulleself, maar vir ander nasies as oordeel $(5: 18)$. Hulle maak of die dag van rampe vir hulleself ver is $(6: 3)$. Hulle het net oorvereenvoudigde benaderings van verkiesing en van straf. Daarin is hulle eiebelang die deurslaggewende faktor en staan die belange van God en die naaste heeltemal op die agtergrond. Israel bekyk die toekoms te veel in terme van berekenbaarheid in hierdie opsig. Daarom sal hulle sowel wat tyd en inhoud betref, met die eskatologiese toekoms ontnugter word.

Selfs in verband met voorbidding is die Here uit hierdie hoek gesien, onberekenbaar. Na deernisvolle voorbidding en die beantwoording in twee agtereenvolgende visioene volg vernietigende straf in die onmiddellik daaropvolgende visioen. Die Here "gaan Israel nie meer spaar nie" (7:8). Vir hierdie strafaankondiging word verwys na "die hoogtes van Isak", "die heiligdomme van 
Israel" en "die koningshuis van Jerobeam" (7:9). Israel perk die Here in hulle verkiesingstradisies in en maak Hom berekenbaar en selfs manipuleerbaar vir hulle doeleindes deur vervalste godsdiens ("hoogtes"). Hulle beoefen 'n kultus wat as 't ware outomaties of magies die gewenste resultate bewerk, en waarin staatsmanipulering van die kultus vir eie doel plaasvind. Op die verwysing in 7:9 volg die gedeelte oor die botsing tussen Amos en die priester Amasia by "die koninklike heiligdom, die staatstempel" (7:10-17). Daarin motiveer Amos sy optrede deur te wys op sy ongevraagde, onberekende en onweerstaanbare roeping en openbaring deur die Here, waarin God se vrymag duidelik na vore kom.

\subsection{Die land}

Ook wat die land betref, maak Israel 'n berekeningsfout. Die land staan nie op sigself nie, maar is die vrug van die verhouding met die Here. Wanneer die land van Hom en sy wil (wet) losgemaak en op sigself gesien word, wanneer daar nie na die wil van die Here gevra word nie, word die land in werklikheid 'n voorwerp van afgodery (5:4-6; vgl. 4:4). Dan word die nood van die swakkes in die land nie raakgesien nie, maar word hul uitgebuit (8:4). Dan word die doel van die uittoggeskiedenis deur Israel gemis en word daardie gebeurtenis deur die Here in sy teendeel omgekeer, naamlik deur die wegvoer in ballingskap $(5: 5,27 ; 6: 7$; 7:10). Dan gaan Hy Israel nie meer deur sy straf verby soos in daardie nag waarna die Pasga verwys nie, maar gaan Hy tussen hulle deur soos tussen die Egiptenaars $(5: 17 ; 8: 2)$.

Israel se optrede teenoor die Here en hulle naaste roep om die algehele vernietiging van so ' $n$ ontroue volk; daarom word daar 'n begrafnislied vir hulle gesing (5:1-3). Hierdie venietiging is nie berekenbaar nie en stuit voor geen grense nie. Selfs daar in die ballingskap waar ander gode volgens die mening van daardie nasies die septer swaai, is Israel nie aan die Here se optrede onttrek nie $(9: 1-4)$. Alles staan onder sy mag en heerskappy. Hy sorg vir die hele aarde $(9: 5,6)$. Daarom gaan Hy Israel losskeur van die land. Israel het die voorreg misbruik om as uitverkore volk in die beloofde land te woon, en het die Here verander van Skeppergod na 'n nasionale God, selfs na 'n groeps-God binne in die land. Maar wie die Here so beperk of berekenbaar maak, word uiteindelik van die aarde af weggevee! (9:8).

Tog sal dit nie die laaste woord oor die saak wees nie. Die Here se genade is onberekenbaar, eindeloos. Hy gaan Israel uit die ruïnes laat opstaan. Hy gaan "die vervalle hut van Dawid weer opbou" en sy mag oor die nasies laat geld: "oor al die nasies oor wie my Naam uitgeroep is" $(9: 11,12)$. In die lig van 9:7 moet hierdie stelling in 'n gunstige sin ten opsigte van die nasies verstaan word (vgl. bo). Israel sal weer in die land woon en die beloftes van oorvloed sal in vervulling gaan (9:13-15). Hier word Israel se toekoms in tipies OuTestamentiese gees in konkrete beelde gestel (vir die betekenis van ruimtelike 
besef en van land in die algemeen en vir Israel in besonder, kyk Olivier, 1996:250, 254, 257). Tog is Israel en die land hier relatief tot God se wêreldwye koningsheerskappy en doel. Een ding staan egter vas: die Here bly getrou aan sy beloftes. Hierin is Hy betroubaar, maar nie berekenbaar nie. Hy is vrymagtig en kan op 'n onverwagte manier uitkoms gee, selfs al ontbreek enige teken van bekering, soos in 9:11-15 die geval is. Daarom is die volgende stelling van O'Kennedy (1997:101) vatbaar vir misverstand en va dit om nadere presisering: "Yahweh's change of mind (relent or repent) is always a response to human behaviour or action, never initiated arbitrarily".

\section{Samevatting en gevolgtrekking}

Die boek Amos sê dat Israel die persoonlike aard van die godsdiens, die persoonlike verhouding met God en die naaste soos in die gebooie vergestalt, misken. Hulle het 'n blinde oog vir reg en geregtigheid en verval in vormgodsdiens, wat in wese neerkom op manipulering van God se wil. Israel is ten volle toerekenbaar en het nie alleen 'n dowe oor vir die bekeringsoproep wat deur die besondere verbondenheid met die Here in hulle geskiedenis tot hulle kom nie, maar maak ook die verkondigers van hierdie wil van die Here stil. Die gevolge is dodelik. Hulle gaan met die Here persoonlik en in sy vrymag te doen kry.

Wat heilsgeskiedenis moes wees, het 'n geskiedenis van straf geword om bekering teweeg te bring, maar voortdurend sonder resultaat. Weens Israel se volgehoue omkering van die doel van hulle geskiedenis gaan die Here in sy vrymag hulle geskiedenis self op sy manier omkeer. In plaas van 'n geskiedenis van redding, ingelei deur die uittog uit Ëgipte en herdenk in die Pasga, toe die Here sy volk met die oordeel verbygegaan het, sal Hy hulle nie meer verbygaan nie, maar hulle juis straf. Israel gaan selfs uit die beloofde land weggevoer word.

Die Here is vrymagtig en daarom nie gebonde aan Israel of sy land nie. Hy trek die grense tussen volke anders as mense, want $\mathrm{Hy}$ is die Skepper, die universele God, en Hy wil as sodanig gedien word. Hy laat Hom nie manipuleer deur kultus, profesie, gebed of enige menslike strukture om alles netjies in berekende pakkette te verpak en so die een menslike teologie te laat geld nie.

Daarom word Amos op ' $n$ buitengewone manier as profeet geroep en moet hy net sê wat die Here hom opdra om te sê. Hy moet 'n meganiese godsdiens waarin God berekenbaar gemaak word, aan die kaak stel en moet nie vanuit 'n geslote teologiese sisteem of verwagting praat nie maar moet die uiteindelike uitkoms in die hand van die Here laat. Die vrymag sny na twee kante: om te straf en af te skryf, maar ook om te vergewe, en wel op God se tyd en wyse. Die benaming "my volk" en die verkiesing kan dus verswarende omstandighede aandui, maar tog tegelyk die Goddelike vrymag tot genadebetoon. Daar kan en moet dus erns 
daarmee gemaak word dat die Here Hom "dalk" sal ontferm en dat daar volgens die treurlied tog oorblywendes uit die oordeel sal wees.

Die profeet Amos se verkondiging is dus nie sonder hoop nie, maar soos dié van Klaagliedere 5:22. Ook daarin word enersyds die vrymag van God erken en word nie sommer dieselfde fout as in Israel se verlede gemaak nie - die fout naamlik van selftevredenheid en valse gerustheid. Andersyds word tog aan God vasgehou (Helberg, 1990:382; Gous, 1990:300). Die vrymag laat nog die deur oop om uiteindelik die genade in die verbondsuitdrukking "jou God" te hoor (9:15; vgl. ook Jer. 31:31-34; Eseg. 36:26-28).

Goddelike vrymag in die boek Amos hou verder enersyds in dat daar groot erns gemaak moet word met reg en geregtigheid. Andersyds word groot ems vereis vir voorbidding vir oortreders eerder as blote veroordeling. Dit gaan vir God om bekering sodat Hy reg gedien word. Hierdie gesindheid moet aan die wortel van almal se motiewe en optredes wees. Ook in hierdie land waarin die begrippe waarheid en versoening tans sterk in die sentrum gestel word, moet hierdie gesindheid geld - veral rondom die Waarheids- en Versoeningskommissie, asook die huidige klimaat van roof, moord, verkragting en ander misdaad.

Vir die Bybelse gelowige word hierdie onberekenbare werklikheid alleen werklik sinvol in die lig van Jesus Christus se vrywillige lyding ter wille van sondaars. Hy het vir hulle voorbidding gedoen "want hulle weet nie wat hulle doen nie". Hy het 'n berouvolle moordenaar aan 'n kruishout vergewe en aan ' $n$ ander berouvolle sondaar gesê: Ek veroordeel jou nie, gaan en moet nie verder sondig nie. Hierdie genadebetoning is moontlik deur die Goddelike vrymag waarop Amos so sterk nadruk gelê het. Reeds in die boek Amos word die wonderbaarlike kant van die vrymag gesien in die onverwagte aankondiging van verlossing. In die Nuwe-Testamentiese bedeling gaan 'n groot lig op: God het in sy onberekenbare vrymag verantwoordelikheid aanvaar vir die skuld: sy Seun Jesus Christus het vrywillig en onskuldig ter wille van ons onreg en ongeregtigheid gely. Van hierdie plaasvervangende lyding sien ons reeds padwysers in die Ou Testament (Jes. 53). God neem die verantwoordelikheid vir wat met "sy volk" gaan gebeur rondom die gebeurtenis van die oorspronklike én omgekeerde Paasfees en uittoggeskiedenis soos dit in die boek Amos gestel word. Hierdie gebeure verteenwoordig ' $n$ geskiedenis waarin God slegs skynbaar harder optree as Israel se vyande. Hierdie vyande wil die Israeliete in ballingskap wegvoer, terwyl God vir Israel daar in die ballingskap selfs met die swaard wil afmaai.

\section{Bibliografie}

ALBERTZ, R. 1992. Religionsgeschichte Israels in alttestamentlicher Zeit. 1. Göttingen : Vandenhoeck \& Ruprecht. (Grundrisse zum Alten Testament. ATD Ergänzungsreihe Band 8/I.) 
BARSTAD, HM. 1984. The religious polemics of Amos. Leiden : Brill. (Supplements to Vetus Testamentum.)

BARTON, J. 1980. Amos's oracles against the nations. Cambridge : Cambridge University Press. (The Society for Old Testament Study. Monograph Series 6.)

CHILDS, B.S. 1979. Introduction to the Old Testament as Scripture. London : SCM.

FENSHAM, F.C. 1970. Exodus. Nijkerk : Callenbach (De Prediking van het Oude Testament.)

FIRTH, D 1996. Promise as polemic. Old Testament Essays, 9(3):372-382.

FRITZ, V. 1987. Die Fremdvölkersprüche des Amos. Vetus Tesıamentum, 37(1):26-38.

GOUS, I.G.P. 1990. Lamentations 5 and the translation of verse 22. Old Testament Essays, $3(3): 287-302$.

HASEL, G.F. 1981. Understanding the book of Amos: Basic issues in current interpretations. Grand Rapids : Baker.

HELBERG, J.L. 1990a. Die verbondsvolk se verhouding tot sy land. Potchefstroom : PU vir CHO, Dept. Sentrale Publikasies.

HELBERG, J.L. 1990b. Land in the book of Lamentations. Zeitschrift fiir die alttestamentliche Wissenschaft, 102(3):381, 382.

JOHNSON, B. 1989. צדק. (In Theologisches Worterbuch zum Alten Testament. VI. Stuttgart : Kohlhammer. p. 898-924.)

KOCH, K. 1976. צ' gemeinschaftstreu/heilvol sein. (In Theologisches Handworterbuch zum Alten Testament. II. München : Kaiser. p. 507-530.)

KOENEN, K. 1994. Heil den Gerechten - Unheil den Sündern! Ein Beitrag zur Theologie der Prophetenbücher. Berlin : Walter de Gruyter. (Beihefte zur Zeitschrift für die alttestamentliche Wissenschaft, 229.)

LIEDKE, G. 1976. שפ richten. (In Theologisches Handwörterbuch zum Alten Testament. II. München : Kaiser. p. 999-1009.)

MARKERT, L. 1977. Struktur lind Bezeichnung des Scheltworts. Berlin : Walter de Gruyter.

MARTIN-ACHARD, R. 1984. Amos. (In Amos \& Lamentations: God's people in crisis. Grand Rapids : Eerdmans. International Theological Commentary. p. 3-71.)

MAYS, J.L. 1974. Amos. Philadelphia : Westminster. (The Old Testament Library.)

MILLER, J.M. \& HAYES, J.H. 1986. A history of ancient Israel and Judah. Philadelphia Westminster.

MOTYER, J.A. 1970. Amos. (In Guthrie, D. \& Motyer, J.A. eds. The new Bible commentary revised. London : InterVarsity Press. p. 726-741.)

ODEN, R.A. Jr. 1987. The place of covenant in the religion of Israel. (In Miller, P.D. et al. eds. Ancient Israelite religion. Philadelphia : Fortress. p. 429-447.)

O'KENNEDY, D.F. 1997. 'It shall not be': divine forgiveness in the intercessory prayers of Amos (7:1-6). Old Testament Essays, 10(1):92-108. 
OLIVIER, J.P.J. 1996. Spatial awareness, an essential element of historical understanding in Old Testament studies. Old Testament Essays, 9(2):249-260.

PRINSLOO, W.S. 1987. Die boek Amos. (In Burden, J.J. \& Prinsloo, W.S. reds. Tweegesprek met God. Kaapstad : Tafelberg. p 239-248. Die literatuur van die Ou Testament. 3.)

PREUSS, H.D. 1992. Theologie des Alten Testaments. II Stuttgart : Kohlhammer.

ROTTZOLL, D.U. 1996. Studien zur Redaktion und Komposition des Amosbuchs. Berlin : Walter de Gruyter. (Beihefte zur Zeitschrift fur die alttestamentliche Wissenschaft, 243.)

RUDOLPH, W. 1971. Amos. Gütersloher Verlagshaus: Gerd Mohn. (Kommentar zum Alten Testament. XIII 2.)

SMITH, G.V. 1989. Amos. Grand Rapids : Zondervan. (Library of Biblical Interpretation.)

SOGGIN, J.A. 1987. The prophet Amos. London : SCM.

STEK, J. 1978. Salvation, justice and liberation in the Old Testament Calvin Theological Journal, 13(2): 133-165.

VAN LEEUWEN, C. 1985. Amos. Nijkerk : Callenbach. (De prediking van het Oude Testament.)

WOLFF, H.W. 1969. Amos. Neukirchen-Vluyn: Neukirchener Verlag (Biblischer Kommentar Altes Testament.) 
